\title{
HEALTH CARE FOR PEOPLE WITH AMPUTATION: ANALYSIS FROM THE PERSPECTIVE OF BIOETHICS ${ }^{1}$
}

\author{
Ana Maria Fernandes Borges Marques², Mara Ambrosina de Oliveira Vargas ${ }^{3}$, Soraia Dornelles Schoeller", \\ Erika Yuriko Kinoshita ${ }^{5}$, Flávia Regina Souza Ramos ${ }^{6}$, Ana Paula Trombetta
}

\footnotetext{
${ }^{1}$ Part of the thesis - Health care for people with amputation in the light of bioethics, linked to the macroproject - Physically disabled people submitted to clincial or traumatic amputation: an analysis from the perspective of bioethics. CNPq Edital Universal 14/2011.

${ }^{2}$ Doctoral student, Graduate Nursing Program (PEN) at Universidade Federal de Santa Catarina (UFSC). Florianópolis, Santa Catarina, Brazil. E-mail: am.borgesmarques@gmail.com

${ }^{3}$ Ph.D. in Nursing. Faculty member, Nursing Department and PEN/UFSC. Florianópolis, Santa Catarina, Brazil. E-mail: ambrosina.mara@ufsc.br

${ }^{4}$ Ph.D. in Nursing. Faculty member, Nursing Department and PEN/UFSC. Florianópolis, Santa Catarina, Brazil. E-mail: soraia. dornelles@ufsc.br

${ }^{5}$ Undergraduate Nursing student at UFSC. Scientific Initiation Grantee. Florianópolis, Santa Catarina, Brazil. E-mail: erikayk167@ gmail.com

${ }^{6}$ Ph.D. in Nursing. Faculty member, Nursing Department and PEN/UFSC. Florianópolis, Santa Catarina, Brazil. E-mail: flavia. ramos@ufsc.br

${ }^{7}$ Doctoral student PEN/UFSC. Nurse at Instituto de Cardiologia de Santa Catarina. Florianópolis, Santa Catarina, Brazil. E-mail: ana_trom@yahoo.com.br
}

\begin{abstract}
A qualitative, descriptive and exploratory study was conducted through semi-structured interviews with 18 people undergoing amputation in the period 2008-2010, in public hospitals in Florianópolis. The objectives were to analyze the care provided by health professionals throughout the amputation process in the perspective of the amputee patient; and discuss the process of health care to the person with amputation in the bioethical analysis perspective. Data were analyzed according to content analysis. Three thematic categories emerged: the process of amputation; team performance and rehabilitation. Bioethics permits reflection on the care provided to amputees and problematizes the relationship of the health care process with support available through public health policies. The professional involved in this process has to take responsibility for putting the process in practice and interdisciplinary is essential for the recovery of the amputated patient.
\end{abstract}

DESCRIPTORS: Amputation. Health professionals. Bioethics. Assistance to health. Public health policy.

\section{O CUIDADO À SAÚDE À PESSOA COM AMPUTAÇÃO: ANÁLISE NA PERSPECTIVA DA BIOÉTICA}

RESUMO: Estudo qualitativo, descritivo e exploratório realizado por entrevista semiestruturada com 18 pessoas submetidas à amputação, no período de 2008 a 2010, em hospitais públicos da Grande Florianópolis-SC. Os objetivos foram analisar a assistência prestada pelos profissionais de saúde em todo o processo de amputação na perspectiva da pessoa com amputação e discutir o processo de assistência à saúde à pessoa com amputação à análise bioética. Os dados foram analisados com base na análise de conteúdo. Emergiram três categorias temáticas: o processo de amputação, atuação da equipe e reabilitação. A bioética possibilita a reflexão acerca da assistência prestada à pessoa com amputação e remete a problematizar a relação processo de assistência à saúde com os subsídios disponibilizados através das políticas públicas de saúde. O profissional envolvido nesse processo necessita responsabilizar-se pela efetivação desse processo e a interdisciplinaridade é essencial para a recuperação da pessoa com amputação.

DESCRITORES: Amputação. Pessoal de saúde. Bioética. Assistência à saúde. Políticas públicas de saúde. 


\title{
EL ATENCIÓN DE SALUD PARA PERSONAS CON AMPUTACIÓN: ANÁLISIS EN LA PERSPECTIVA DE LA BIOÉTICA
}

\begin{abstract}
RESUMEN: Estudio cualitativo, descriptivo y exploratorio desarrollado mediante entrevistas semiestructuradas con 18 personas sometidas a amputación en el período de 2008-2010, en hospitales públicos de Florianópolis. Los objetivos fueron analizar la atención brindada por profesionales de salud en todo el proceso de amputación en la perspectiva de la persona con amputación; y discutir el proceso de asistencia a la salud a la persona con amputación de la bioética análisis de perspectiva. Los datos fueron analizados según el análisis de contenido. Emergieron tres categorías temáticas: proceso de amputación; actuación del equipo y rehabilitación. La bioética posibilita la reflexión sobre la atención brindada a personas con amputación y problematiza la relación del proceso de atención en salud con los subsidios disponibles a través de las políticas públicas de salud. El profesional involucrado en este proceso se necesita responsabilizar por la efectuación del proceso y la interdisciplinaridad es esencial para la recuperación de la persona con amputación DESCRIPTORES: Amputación. Profesionales de salud. Bioética. Asistencia a salud. Políticas públicas de salud.
\end{abstract}

\section{INTRODUCTION}

Amputation is classified as a physical disability, as physical disability refers to an alteration that makes the expected and appropriate performance of the physical function of a given part of the affected body impossible. ${ }^{1}$ According to the 2010 Census undertaken in Brazil by the Brazilian Institute for Geography and Statistics (IBGE), approximately $24 \%$ of the Brazilian population has some disability. About $7 \%$ of this population has a motor disability, representing approximately 3 million Brazilians. ${ }^{2}$

The Federal Constitution and the Principles and Guidelines of the Unified Health System (SUS) led to the emergence of decrees and laws to support disabled people, their social integration, care priorities and criteria to promote accessibility. Chapter II of the Federal Constitution, article 23, discusses that "it is the shared competency of the Union, States, Federal District and Cities to take care of public health and assistance, of the protection and guarantee of disabled people" $3: 3$

Each day, health professionals face ethical dilemmas, such as inequalities in living condition, system users' access to health services and the lack of preparation/qualification of the human resources in health. In that sense, the reflections originating in the bioethics of protection and intervention are (or should be) present in the effectiveness of public policies. ${ }^{4}$

The bioethics of protection and the bioethics of intervention are a subset of bioethics related to the population's problems in the age of globalization. The bioethics of protection is revealed in the group, indicating the right to accessibility and the need for awareness raising and action with a view to big social changes. The relevance of public health in Latin America needs to incorporate the act of "protecting" those who need care, called wounded, differently from the vulnerable. That is, the wounded are those who, due to actual situations, face problem that affect their living conditions or health status; the vulnerable include society, as anyone can catch something that interferes in the living condition or health status. ${ }^{5}$ Reflections on the bioethics of intervention, on the other hand, signal that social inclusion is related to the daily life of each person, and guide decisions and attitudes. ${ }^{6}$ It supports the discussion on health justice, social inclusion, autonomy and citizenship. ${ }^{4}$

To the extent that the bioethics of protection and intervention attempt to grant visibility to the equality/inequality or equity/inequity among people, they can provide competent support to make them understand their rights and claim them. ${ }^{6}$ "The right to health needs to combine the protection of individual autonomy and the collective provision of means to put that right in practice" .7288

It is considered relevant to contextualize the health care process to amputated people since the hospitalization until the acquisition of the prosthesis to adapt to the new living condition and determine the bioethical aspects involved in this process. In that sense, the research question in this study was: how did health care to people submitted to limb amputation take place from the perspective of bioethical analysis? And the study objectives were: to analyze the care delivered by health professionals throughout the amputation process from the perspective of the amputees and discuss the health care process for amputated people from the perspective of bioethical analysis.

\section{METHOD}

Exploratory and descriptive qualitative study, undertaken at public hospitals in Greater Florianópolis, which are referral institutions for orthopedic/trauma and vascular surgery. After approval by the Ethics Committee for Research 
Involving Human Beings at Universidade Federal de Santa Catarina, under opinion 95.521, authorization for access was obtained from the board of each research hospital. The records of the surgeries performed were provided by the statistics sector of each research hospital: Hospitais Governador Celso Ramos/Florianópolis (HGCR); Hospital Universitário da Universidade Federal de Santa Catarina- Florianópolis (HU/UFSC); Hospital Regional Homero de Miranda Gomes/São José (HRSJ) and Instituto de Cardiologia de Santa Catarina/São José (ICSC).

To discover the number of lower and/or upper limb amputations, except for extremities, the records filed at the statistics sector of each research hospital were screened for the terms: amputation; lower limb amputation; upper limb amputation and disarticulation. The International Classification of Diseases (ICD) related to the amputation was used to perform the search at the HU only: S88 (traumatic amputation at knee level) and Y83.5 (amputation of limbs). The inclusion criteria were: people over 18 years of age, submitted to upper and/or lower limb amputation, except for extremities, between 2008 and 2010 at the research hospitals and living in Greater Florianópolis; being able to communicate, according to the researchers' subjective assessment. The exclusion criteria were: age over 85 years and death. In total, 124 records of surgeries were found.

To select the participants, the 124 preselected records were contacted by phone and, if contact was possible, they were asked whether they accepted to participate in the research or not. In this group, 24 amputated people could be contacted, 18 of whom accepted to participate in the study. The research participants signed the Informed Consent Form, which authorized the investigation of the patient history and the participation in a semistructured interview, with an average duration of 40 minutes, which was digitally recorded. The interviews were held at the participants' homes, except for one, held at the participant's place of study. The data collected from the histories followed a pre-established form that contained the variables: sex, age, year of amputation, place of amputation, previous amputations, cause of problem, associated diseases, marital status, education and occupation. The participants' identification was alphanumerical, consisting of the year of the amputation $(08=2008,09=2009,10=2010)$, sex $(\mathrm{F}=$ Female, $\mathrm{M}=$ Male) and the number of the interview (I, II, III, IV). To organize the data, the software ATLAS-Ti was used. To analyze the interviews, thematic content analysis was applied. The criteria established for this analysis were followed: pre-analysis, categorization, inference, description and interpretation. ${ }^{8}$ After the transcription of the interviews, they were subject to in-depth reading, revealing pre-categories of analysis that were combined based on similarity in thematic groups, constituting larger categories. Thus, the collected data could be interpreted, involving the description and interpretation of the selected statements, articulated with the literature, from the perspective of bioethics.

\section{RESULTS}

Eighteen people participated in the study, who underwent an amputation between 2008 and 2010. The participants' characteristics revealed that 12 are male and 14 were over 50 years of age at the time of the amputation. The main causes were related to vascular disease, gangrene, diabetic complications and infectious processes; Diabetes Mellitus (DM) was the baseline disease for all participants and only one person did not suffer from systemic arterial hypertension. Among the interviewees, eight had undergone earlier amputations and three had an amputation related to a traffic accident.

As regards education: six had not finished primary education, six had finished secondary education, four high school and one was taking higher education. Among the 18 participants, 11 were married, three widowed, two divorced and two single. Concerning the current occupation: 14 were retired/pensioners, five of them due to disability related to the amputation; three received a disease benefit and one is an athlete and swimming teacher.

After the transcription and analysis process of the interviews with the amputated people, three thematic categories emerged related to the study objectives: The amputation process; The team's activities and Rehabilitation.

\section{The amputation process}

The amputation process is sometimes long. Before the amputation, different procedures are accomplished in the attempt to save the limb.

I started amputating my finger in 98 [...]. I crashed my care and broke my finger, it did not heal and they had to amputate it. Then, I started feeling 
pain in my leg when I walked [...], I went there and they said it was a circulation problem. In 2006, they did a surgery to free the arteries. In 2008, however, the circulation stopped in my leg and then they really amputated (08MXI).

Despite knowing the ideal place of the amputation, based on the following report by one of the research informants, it can be inferred that many professionals first choose to satisfy the patient's need, although they are aware that another amputation will take place later on.

The wound started in the middle of the fingers and it started rotting. For three months I slept sitting in the couch, if my leg paired up with my body I got crazy [...]. When I decided to go to the hospital, the doctor said: 'the solution is to amputate your leg.' I went mad. Then, to satisfy me, they cut half of my foot. The foot rotted [...], they did an angioplasty, I felt blood boiling here in my groin. That suffering. I spent 23 days in hospital, and they amputated the leg, I was between life and death (10MX).

When there is a death risk, priorities are set to hemodynamically re-establish the patient and preserving the limb is not always possible.

I also broke the femur and the fat of the femur went to the lung, then they cleaned the lung [...]. I had three respiratory arrests [...] they left the leg on, the circulation stopped, necrosis developed and they had to amputate [...]. I regained consciousness and my leg was still there, they had reconstituted it completely, but then the respiratory arrest happened, they stopped taking care of the leg and necrosis started and it was amputated, because they took care of the lung and, if they didn't, I could die! (09MII).

\section{The team's activities}

The team's activities are very important in care delivery to people who are about to be amputated, so as to keep them informed of all procedures and show that they are essential in this process, permitting recovery.

Everyone treated me very well at the hospital. The physicians, the nurses were good. The physicians used to sit at my headrest and say: 'you won't walk, take care now that you don't have one leg, use a crutch and put it at your bedside for when you get out or it's preferable to move on the floor like a kitten, at least you don't fall' (09FIII).

The explanation they gave it was the nurse, while doing the dressing, he explained that the anklebone no longer existed, none of the doctors gave an exact explanation (08MXVI).
What helped me a lot too was the nutritionist, and she was there since the start monitoring, she used to give me special shakes (10MIX).

I was in the hospital twice, the girl looked at my leg, did the dressing, then the doctor looked and sent me away [...]. They did not explain what I had and I used to stay there (08FV).

Being able to listen to the complaint of the patient and taking appropriate care are aspects signaled in the following statements.

They were very polite, but we used to say that it was hurting [...] but they did not pay attention to me, they didn't even want to know (09MII).

I felt like shit, they didn't consult me. They should have prepared me: 'I' $m$ going to do a cleaning and who knows remove a bit more'. But now, I came back calm, with my foot bandaged. The anesthesia passed and, when I moved my foot, 'what, it seems that my foot is not there! (10MIV).

The participants' statements express the extent to which the infrastructure available for this type of care influences the people who need it, that is, not only the amputated patient, but the health professional as well.

Something happened in my second surgery. It had been scheduled for eight in the morning and I had the surgery at four in the afternoon. That was because, when my parents noticed that the surgery would not happened, they called an acquaintance to do something and I had the surgery [...]. There was always an emergency arriving (08FXVII).

At the time, the hospital director did not authorize the physician to operate with the best material, which was not covered by the SUS, [...] alleging that it served for senior citizens, when this type of fracture is more normal [...]. That's what I resent with regard to the hospital [...], if it weren't for that I'd be normal, walking around with the prosthesis. The doctor was most willing (10MXVIII).

\section{Rehabilitation}

The multidisciplinary team's activities further the rehabilitation, in an interdisciplinary manner. But the discourse does not characterize this care:

[...] only by nursing, they did the dressing and took care of the prosthesis (08MI).

[...] only with the physiotherapist, and there was the prosthesis technician (08FXVII).

The following statement, in turn, evidences the need for these people to enhance their criti- 
cal skills with regard to their own rehabilitation process.

If the physiotherapist accompanied me since my discharge to bed, for strengthening, it helped for me to stand. As soon as I was discharged home, I talked to a friend who's a physiotherapist and he came. In few weeks I was already standing (10MIX).

The amputated people demand specific rehabilitation care. In that sense, the professionals need to be prepared to work competently.

The staff from the health service came to my house twice to do the dressing, but the second time the girl got frightened and insecure, then I didn't want that anymore (08FXVII).

I went to Palhoça, there was a bone physician there, an orthopedist. He said: 'I don't want those papers of yours, I want other tests'. I did the tests. When I returned, he said: 'you cannot use your leg. Everything will rot inside your leg. You have diabetes' (08FV).

This rehabilitation process includes the acquisition of the prosthesis and the respective forwarding, but there is not standard for the care and the trajectory. In addition, the disuse of the prosthesis is identified.

The forwarding started at the hospital with Dr. $Y$, he knew Dr. X. from the Rehabilitation Center. He elaborated a document, we scheduled the appointment [...] it took two years for the prosthesis. Before that, we bought a prosthesis that did not work [...]. I spent one year without prosthesis (10MIX).

A year and a half to get the prosthesis, you need the cardiologist to see how the heart, kidney, lung is doing [...]. I got a temporary one to thin the leg and, after I had used that for three months, I would get a real one to fit and stay there, but they said there's a crisis, the government should first pay for the prosthesis for me to get it (09MVIII).

Finally, based on the report, a different in the prosthesis material is perceived, when it comes from the SUS or not.

The quality of the SUS prosthesis is bad, the parts are all national. It's a good prosthesis if you can't get a better one, but it's uncomfortable and, as I was already using mine, which is different, when I got the SUS', I continued using what I had (08FXVII).

\section{DISCUSSION}

The study findings with regard to sex and amputation cause indicate what the other studies also evidence. That is, men and the baseline disease DM predominate with regard to amputation. DM is a risk factor for amputation. ${ }^{9-11}$

As observed, the participants' education level is low, based on which it is considered that knowledge deficits, especially in the male population, about the importance of health promotion and disease prevention, influences self-care ${ }^{12}$ actions and their "competence" to contextualize their rights in the health care process. The research participants, whether married or not, live with their family, legitimizing it as support for health promotion and disease prevention.

It was verified that the causes leading to amputation can be triggered by a chronic illness as well as by trauma, the latter determined by external causes. Despite different motives for the amputation, however, the care process is the same. In other words, based on the statements, it can be inferred that, despite the stakeholders' different ages and needs, both end up in the same health care context: slow and fragmented.

The feelings triggered by the imminent amputation are similar in the people going through this situation. After all, both are confronted with a new living condition, besides the duality between the need for the surgery and the "refusal" to lose part of themselves. ${ }^{13}$ Hence, accepting that the amputation is the best option is not easy, as the way the people see themselves in society changes, giving rise to countless problems. The patients are wounded for the situations triggered with regard to their new condition; they are not prepared to discern what is ideal to establish better living conditions.

When prioritizing the opinion of people to whom an amputation has been indicated, it should be considered whether they knew their condition and that certain conducts will directly influence their recovery. The care provided needs to be focused on an effective intervention, aiming to protect the victims. Hence, the following question is raised for reflection: is protection the conduct that attends to the "desire" of the patient, even if the professional is aware that more suffering will follow? What are the consequences of taking and following that decision? What impacts can result from the use of other options? The bias of the best intervention is often to deliberate on what is the best thing to do, taking into account the complexity of this type of care.

Permitting the practice of autonomy means offering information on the best conducts to be taken; it means inserting the patients in the care process; it means knowing how to listen to them, 
knowing their weaknesses and providing for tools for them to feel capable and responsible for their recovery. Thus, the respect for autonomy is related to enabling the person to move beyond their concept of dependence. ${ }^{14}$ It should be underlined, however, that so-called autonomous persons can also make mistakes in their decisions made, as the conditions experienced at the moment of the decision directly interfere in their actions.

It is believed that clarifying the risks and benefits of care delivery avoids any bottleneck in the conduct taken. It is fundamental for the patients to know the pros and cons of the care performed, so as not to create mistaken expectations regarding that care. ${ }^{15}$

One of the reports evidences the action of preserving life, where the most objective of care was to hemodynamically re-establish the person, turning the attempt to save the limb into the second option. In this context, deciding on what conduct to take requires countless reflections, although it is important to establish those that permit better living conditions. In view of a vulnerable being at imminent risk of death, the act of protecting is to recover the hemodynamic balance. The participant's discourse reveals that he understand the sequence of conducts followed. Nevertheless, this person expressed that he felt weakened in view of the situation and was incapable of fully participating in the care process. That situation contains a paradox: one lives in a world in which technologies emerge all the time that aim to grant better living conditions to the people who need it, so why not think of the combined possibility of guaranteeing life, saving the limb and permitting a better quality of life at the same time?

The multidisciplinary activity results in greater safety with regard to the decision made, permitting greater benefits for the people considered as risk groups. The professionals' experience and the available technological apparatus are aspects considered in the care strategies adopted, in accordance with the complexity of the lesion. ${ }^{15}$

The health professionals should acknowledge the needs of the patients submitted to the amputation, so that the orientations provided influence the short, medium and long-term recovery and, hence, the prevention of health problems associated with the amputation. The care the team provides should move beyond the physical and prosthesis focus; after all, in the course of the entire amputation process, psychological and social interventions are also essential. ${ }^{16}$
The people who receive care sometimes do not know that that care is a right and not a favor granted by the person who provides it. In that sense, one of the participants praises the health team's activities. It can be inferred, however, that compliments for the professionals' care evidence the patients' lack of knowledge of their right to high-quality care.

The bioethics of protection is one way to reflect on the functioning of the public health system structure, in which the State is responsible for resource management, social control and qualified human resources ${ }^{6}$ and for providing/developing techniques aimed at reducing the stakeholders' disabilities. $^{4}$

In the study participants' reports, it is highlighted that interdisciplinary actions are a problem. The amputated people see the professionals in an isolated manner; the function of each is acknowledged, but not the perceived importance of interdisciplinary care. Nevertheless, in a multidisciplinary team's care process, when acting in an interdisciplinary manner, communication is more effective and, consequently, the patients' recovery and rehabilitation process can be more satisfactory. ${ }^{11,17-18}$

Knowing how to listen is essential; this conception is also articulated with the professionals' attitudes and work conditions. As early as in 2003, the Federal Government launched the National Humanization Policy, aiming to promote communication among managers, workers and patients attended by the Unified Health System (SUS). In that policy, it was indicated that, although the patient is co-accountable in health production, the care and management of the work processes should be focused on the needs of the citizens who seek care. Thus, Humaniza SUS, during the ten years since its creation, has aimed for knowledge exchange and multiprofessional teamwork based on cross-sectionality. ${ }^{19}$

As observed, the precarious infrastructure, associated with nonchalant care, leads to inappropriate care delivery, infringing on the rights of the people who need it. Health professionals are educators who should promote health and prevent diseases and complications, reducing the problems that affect the vulnerable society. ${ }^{20}$ Therefore, it is the duty of the State to offer a qualified and valued team and guarantee infrastructure and quality. Nevertheless, simply presenting policies is not sufficient, but means are needed to execute them. Rights have been gained through the constitution and they have to be respected. 
The reports showed that, when care is provided in an isolated manner, the expected outcome may not be evidenced. Therefore, it is considered that a treatment plan centered on the person should be comprehensive and developed from the start of the rehabilitation process. ${ }^{17,20}$ Rehabilitation should be planned even before the amputation, because the team understands the importance of the early establishment of rehabilitation.

According to one study, health professionals, particularly in primary care, feel unprepared to deliver care to disabled people, especially people who were amputated, showing the lack of knowledge on the importance of rehabilitation. ${ }^{21}$ The National Health Promotion Policy determines that primary health care should solve most of the health needs evidenced by the population. ${ }^{22}$

In that perspective, it is considered that a knowledgeable health team can plan, organize, develop and assess actions that grant better living conditions $^{23}$ to wounded people. ${ }^{22}$ Nevertheless, the professionals' lack of preparation is evidenced, which exacerbates avoidable situations, turning the recovery process even slower than expected. ${ }^{21,23}$

The study also evidences the team's lack of experience in comprehensive care to amputated people and their relatives. These individuals figure among the people who display multifactorial consequences due to the new living condition which, by itself, turns into a challenge for the professionals involved in care. ${ }^{21,23}$

As regards the acquisition of the prosthesis, it should be reminded that, in the state where the study was developed, there is only one referral center for rehabilitation, which is unable to attend to the demand. This problem directly influences the rehabilitation process of amputated people. After all, care planning should be centered on the patient's social wellbeing and developed at the start of the rehabilitation process. ${ }^{17}$

Hence, questions are raised on the State's responsibility in resource management. In 2012, the Care Network for Disabled People was created, which offers financial incentives for specialized rehabilitation care centers, with a view to guaranteeing access to the people who need the service. ${ }^{24}$

Based on the analysis of the reports, it is considered that the care trajectory the study participants followed was disorganized and that there is a lack of information about each person's rights with regard to the new condition. This finding differs from the legislation in force in Brazil. Article 23 in chapter II of the Federal Constitution determines that the Union, State and Cities are responsible for offering public health and care conditions to disabled people. ${ }^{3}$ In that sense, the Care Network for Disabled People emerges to permit the execution of this right guaranteed in the Federal Constitution.

One of the participants addressed the quality of the prosthesis material. After all, bad-quality material directly influences the use of the prosthesis or not. The decree that establishes the Care Network for Disabled People determines on the availability of resources to purchase materials in order to offer prostheses. ${ }^{23}$

Concerning the non-acquisition of the prosthesis, this is related to the bureaucracy required in the course of the amputation process, evidencing yet another situation of vulnerability. In that sense, the State should contextualize the bottlenecks and excess bureaucracy and permit guaranteeing that the people who need it can get such prosthesis.

Again, the Care Network for Disabled People emerges to eliminate the difficulties to get access to rehabilitation services, besides the other services of the Health Care Network..$^{23}$ As something innovative, however, the results of this network will be evidenced in the future, which cannot be distant, as society needs to feel safe in view of the available care services.

\section{CONCLUSIONS}

The study permits reflecting on care for amputated people from a bioethical perspective, considering that studies on this theme focus the discussion on the stakeholders' characteristics, the professionals' care and the amputated people's experience. In other words, no previous studies are available that analyzed the bioethical aspects of the health care process for amputated people.

Therefore, it was considered that the bioethics of protection and intervention is a productive possibility for the process of reflecting on the care delivered to amputated people. It is highlighted that both contribute to the detailed arguments on the several and different subsidies deriving from public health policies that can intervene in the quality of care delivery and transform the people submitted to the amputation or not, enabling them to reflect on their rehabilitation and new living condition.

In addition, in the interval of almost four years since they were submitted to the respective amputation, a precarious situation of physical, so- 
cial and economic independence was evidenced. In short, these qualitative research results do not permit generalizations but questions: is these people's right to citizenship being guarantee? The question is: the amputated people and/or the health team's lack of knowledge, or the disorganization of the health care process?

Studies are needed that focus on the activities of amputated people, observing whether they readapt to the new living condition and develop a high-quality life or not. As evidenced, the professionals' activities in the course of the care process to disabled people are relevant for their rehabilitation to the "new life". Based on these professionals' perspective, the care network should be acknowledged that is established for care to disabled people.

\section{REFERENCES}

1. Brasil. Lei n. 3.298, 20 de dezembro de 1999. Política Nacional para a Integração da Pessoa Portadora de Deficiência [página na internet]. Brasília (DF). [acesso 2012 Mai 01]. Disponível em: http:/ / portal. mec.gov.br/seesp/arquivos/pdf/dec3298.pdf

2. Instituto Brasileiro de Geografia e Estatística. Censo 2010 [página na internet]. 2013 [acesso 2013 Ago 14]. Disponível em: http://www.ibge. gov.br/home/estatistica/populacao/censo2010/ caracteristicas_religiao_deficiencia/caracteristicas_ religiao_deficiencia_tab_gregioes_xls.shtm

3. Ministério da Saúde (BR). Política Nacional de Saúde da Pessoa com Deficiência [página na internet]. Brasília (DF): MS; 2010 [acesso 2012 Mai 01]. Disponível em: http://bvsms.saude.gov.br/ bvs/publicacoes/politica_nacional_pessoa_com_ deficiencia.pdf

4. Vargas MAO. Ética, bioética e biopolítica: conceitos implicados na assistência à saúde. In: Guerreiro D, Almeida AM, Meirelles BHS, Alves LMM, Vargas $\mathrm{MAO}$, Zanetti ML, et al. Curso de Especialização em Linhas de Cuidado em Enfermagem [página na internet] - Módulo V: Doenças crônicas não transmissíveis. 2013 [acesso 2013 Ago 30]. Disponível em: http:/ / unasus2.moodle.ufsc.br/pluginfile. php/11071/mod_resource/content/3/Modulo5_ DoencasCronicas.pdf

5. Siqueira BR, Schramm FRA. Bioética da proteção e a compaixão laica: o debate moral sobre a eutanásia. Ciênc Saúde Coletiva. 2009; 14(4):1241-50.

6. Garrafa V. Proteção e acesso à saúde com um bem social. In: Hellmann F, Verdi M, Gabrielli R, Caponi S. Bioética e saúde coletiva: perspectivas e desafios contemporâneos. Florianópolis (SC): DIOESC, 2012.

7. Junges JR. Direito à saúde, biopoder e bioética. Interface (Botucatu) [online]. 2009 [acesso 2013
Ago 27]; 13(29). Disponível em: http:/ / www. scielo.br/scielo.php?script=sci_arttext\&pid=S141432832009000200004\&lng=en\&nrm=iso

8. Gomes R. Análise e interpretação de dados de pesquisa qualitativa. In: Minayo MCS, Deslandes SF, Gomes R. Pesquisa social: teoria, método e criatividade. 31 ${ }^{\mathrm{a}}$ ed. Petrópolis (RJ): Vozes, 2012.

9. Alvarsson A, Sandgren B, Wendel C, Alvarsson M, Brismar K. A retrospective analysis of amputation rates in diabetic patients: can lower extremity amputations be further prevented? Cardiovasc Diabetol [online]. 2012 [acesso 2013 Jul 10]; 11(18):111. Disponível em: http:/ / www.ncbi.nlm.nih.gov/ pmc/articles/PMC3362773/pdf/1475-2840-11-18. pdf

10. Holman N, Young RJ, Jeffcoate WJ. Variation in the recorded incidence of amputation of the lower limb in England.J Vasc Surg [online]. 2012 [acesso 2013 Jul 20]; 55(7):1919-25. Disponível em: http:/ / link.springer. com/article/10.1007\%2Fs00125-012-2468-6/fulltext. html

11. Andrews KL. The at-risk foot: what to do before and after amputation. J Vasc Nurs; 2011 [acesso 2013 Jul 15]; 29(3):120-3. Disponível em: http:// www.sciencedirect.com/science/article/pii/ S1062030311001142\#

12. Fontes WD, Barboza TM, Leite MC, Fonseca RLS, Santos LCF, Nery TCL. Atenção à saúde do homem: interlocução entre ensino e serviço. Acta Paul Enferm [online]. 2011 [acesso 2013 Set 6]; 24(3). Disponível em: http:/ / www.scielo.br/scielo.php?script=sci arttext\&pid=S0103-21002011000300020\&lng=en\& nrm=iso

13. Gabarra LM, Crepaldi MA. Aspectos psicológicos da cirurgia de amputação. Aletheia, 2009 [acesso 2012 Mai 10]; (30):59-72. Disponível em: http://pepsic. bvsalud.org/pdf/aletheia/n30/n30a06.pdf

14. Vargas MAO. Ética em saúde: autonomia do usuário com DCNT. In: Guerreiro D, Almeida AM, Meirelles BHS, Alves LMM, Vargas MAO, Zanetti ML, et al. Curso de Especialização em Linhas de Cuidado em Enfermagem - Módulo VII: Doenças crônicas não transmissíveis, 2013b [acesso 2013 Ago 13]. Disponível em: https:/ / unasus2.moodle.ufsc.br/ pluginfile.php/12091/mod_resource/content/3/ Modulo7_DoencasCronicas.pdf

15. Magalhães CEV, Ferreira E. Doença vascular periférica acima e abaixo do diafragma: a equipe médica e intervencionista devem atuar juntos? Rev HUPE [online]. 2013 [acesso 302013 Ago 30]; 12(Supl1):81-92. Disponível em: http://www.epublicacoes.uerj.br/index.php/revistahupe/ article/view/7086/5078

16. Liu F, Williams RM, Liu HE, ChienNH. The lived experience of persons with lower extremity amputation. J Clin Nurs [online]. 2010 [acesso 2013 Ago 15]; 19(15-16):2152-61. Disponível em: http:/ / 
onlinelibrary.wiley.com/doi/10.1111/j.13652702.2010.03256.x/pdf

17. Latlief G, Elnitsky C, Hughes SH, Phillips SL, Koss LA, Kent R, et al. Patient safety in the rehabilitation of the adult with an amputation. Phys Med Rehabil Clin N Am [online]. 2012 [acesso 2013 Ago 15]; 23(2):377-92. Disponível em: http://ac.els-cdn.com/S1047965112000198/1-s2.0S1047965112000198-main.pdf?_tid=610b35f8-20d311e3-bebb-00000aab0f01\&acdnat $=1379557979$ ad029fdcc5c7610c2aee39416b097de9>

18. Schoeller SD, Silva DMGV, Vargas MAO, Borges AMF, Pires DEP, Bonetti A. Características das pessoas amputadas atendidas em um centro de reabilitação. Rev Enferm UFPE [online]. 2013 [acesso 2013 Ago 15]; 7(2):445-51. Disponível em: http:// www.revista.ufpe.br/revistaenfermagem/index. $\mathrm{php} / \mathrm{revista} /$ article/download/3351/5326

19. Ministério da Saúde (BR) Política Nacional de Humanização [página na internet]. Brasília (DF): MS; 2004 [acesso 2013 Ago 19]. Disponível em: http://bvsms.saude.gov.br/bvs/publicacoes/ humanizasus_2004.pdf

20. Senra H, Oliveira RA, Leal I, Vieira C. Beyond the body image: a qualitative study on how adults experience lower limb amputation. Clin Rehabil [online]. 2012 [acesso 2012 Ago 17]. 26(2):180-
91. Disponível em: http://cre.sagepub.com/ content/26/2/180.full.pdf+html

21. Baena $\mathrm{CP}$, Soares MCF. Subsídios reunidos junto à equipe de saúde para a inserção da fisioterapia na Estratégia Saúde da Família. Fisioter Mov [online]. 2012 [acesso 2013 Ago 23]; 25(2). Disponível em: http://scielo.br/scielo.php?script=sci_arttext\&pid=S0103-51502012000200020\&lng=en\&nrm=iso

22. Ministério da Saúde (BR). Secretaria de Vigilância em Saúde. Política nacional de promoção da saúde/ Ministério da Saúde, Secretaria de Atenção à Saúde [página na internet]. Brasília (DF): MS; 2006 [acesso 2013 Ago 19]. Disponível em: http:// portal.saude. gov.br/portal/arquivos/pdf/pactovolume7.pdf

23. Mattioni FC, Budó MLD, Schimith MD. O exercício da integralidade em uma equipe da estratégia saúde da família: saberes e práticas. Texto Contexto Enferm [online]. 2011 Jun [acesso 2014 Jan 15]; 20(2):263-71. Disponível em: http://www.scielo. br / scielo.php?script=sci_arttext\&pid=S010407072011000200007\&lng=pt

24. Brasil. Portaria n. 793 de 24 de abril de 2012. Rede de cuidados à pessoa com deficiência no âmbito do Sistema Único de Saúde [online]. 2012 [acesso 2013 Ago 20]. Disponível em: http://bvsms.saude.gov. br/bvs/saudelegis/gm/2012/prt0793_24_04_2012. html 